\title{
Law Enforcement against Pedicap which is Modified into "Bentor"
}

\author{
Ryke Rhimadhila*) and Bambang Tri Bawono**)
}

*) Student of Masters (S2) of Law Faculty of Law Unissula and Staff of Polrestabes Semarang, E-mail: rykerhimadhila@gmail.com

${ }^{* *}$ Faculty of Law, Universitas Islam Sultan Agung (UNISSULA) Semarang

\begin{abstract}
.
The aim of this study To find out and analyze the causes of the many pedicabs being modified into motorized pedicabs in the jurisdiction of the Semarang Police, law enforcement of Act No. 22 of 2009 concerning Road Traffic and Transportation against bumps in the jurisdiction of the Semarang Police, obstacles and solutions in overcoming pedicab law enforcement modified in the jurisdiction of the Semarang Police. The approach method used is juridical normative and juridical sosilogis, the specifications in this research are descriptive analysis, population and sampling methods, data collection techniques using literature study and interviews, data analysis used is qualitative. The research problem is analyzed by law enforcement theory and law effectiveness theory. The number of Bentors as urban transportation shows an increase, this is due to the increasing need for transportation facilities and also transportation service areas that cannot be served by other transportation facilities, because of the difficulty of finding work, many unemployment. Law enforcement against Bentor violations in the jurisdiction of the Unit Polrestabes Semarang refers to Article: 277 of Act No. 22 of 2009. Law enforcement of Act No. 22 of 2009 concerning Highway Traffic and Transportation regarding the prohibition of driving motorized pedicabs has several obstacles, namely the law enforcement factor. The second is the factor of facilities or facilities, namely in the case of confiscation of vehicles where the Police cannot secure large numbers of bumps because the facilities used to transport the bumps are insufficient, the number of Bentors in Semarang. The last factor is the low level of public awareness of the enactment of Act No. 22 of 2009, besides that the community also does not understand the consequences that will be received if they still use Bentor. The solution in overcoming obstacles is by coordinating the Semarang Police with the Semarang City Transportation Agency in enforcing the motorized pedicab law in the city of Semarang as follows: Unity of action, communication, division of labor and strengthening through law.

Key words: Law Enforcement; Modified; Pedicab; Bentor; Traffic.
\end{abstract}

\section{Introduction}

Transportation or transportation is a means needed by the Indonesian people in their daily life. This transportation is very much needed by the people of Indonesia because of many factors, including the geographical condition of Indonesia which consists of thousands of islands, waters which are mostly in the form of oceans, which encourages transportation to be needed by land, sea and air to reach the territory of the Republic of Indonesia. All of that is also for the survival of every society in Indonesia, because without transportation it will complicate the existing life process.

The influence of industrialization, which is identical to the use of machines in various fields of life, also affects the development of transportation. Humans began to create motorized transportation such as motorbikes, cars, planes, trains, ships and including motorized tricycles and others. The existence of a motorized 
rickshaw has caused controversy in several areas, due to problems with traffic laws, city spatial planning regulations and competition with other public transportation.

The increasing population and the growing economy in developing countries like Indonesia require people to have high mobility in order to fulfill their daily needs. To be able to have high mobility, people certainly need a means or means of transportation, besides that currently the means of transportation are widely used by community is land transportation, namely private or public transportation. Article 34 paragraph 3 of the 1945 Constitution states that "the State is responsible for the provision of proper health service facilities and public service facilities".

In addition to public transportation in the form of four-wheeled vehicles, people also use other alternative transportation such as motorbikes and pedicap. Pedicap is a very popular means of transportation in Indonesia. This vehicle is a modification of a two-wheeled bicycle. The development of pedicab transportation in Indonesia varies from region to region. Along with technological developments, pedicab pedals began to be modified using a motorbike drive, or what was known as a motorized rickshaw, hereinafter referred to as Bentor. Modification of motorized vehicles has the provisions of the applicable vehicle modification technical requirements.

Traffic in Indonesia is regulated in statutory regulations, namely Act No. 22 Of 2009 concerning Road Traffic and Transportation, in which the law is made to ensure security, order and welfare in society which need to determine prohibited and required actions. 3

In modifying vehicles regulated in Act No. 22 of 2009 concerning Road Traffic and Transportation, there are also other regulations in Article 132 paragraph (5) and (6) Government Regulation Number 55 of 2012 which means "Modification of vehicles or carrying capacity can be done on motorized vehicles that only add axles without changing the axis or shape, which must be calculated according to the carrying capacity of the road being traversed." Regarding vehicles whose existence is an explanation of Act No. 22 of 2009 concerning Road Traffic and Transportation.

The provisions of the technical requirements for motor vehicle modification are in Act No. 22 of 2009 concerning Road Traffic and Transportation it is contained in Article 50, namely: ${ }^{1}$

a. The type test as referred to in Article 49 paragraph (2) letter a shall be carried out for every Motor Vehicle, trailer and attached carriage imported, manufactured and / or assembled domestically, as well as modification of Motor Vehicles causing a change in type.

b. Type test as intended in paragraph (1) consists of:

1) Physical testing to fulfill the technical requirements and roadworthiness which is carried out on the runway of Motorized Vehicles and Motor Vehicles in complete condition; and

2) Research on the design and engineering of Motor Vehicles carried out on houses, troughs of cargo, trailers, attached carriages, and modified motor vehicles.

${ }^{1}$ Act No. 22 of 2009 concerning Road Traffic and Transportation 
As for the provisions regarding Article 1 number 12 in Government Regulation Number 55 of 2012 concerning vehicles (PP No. 55/2012), it explains that motorized vehicle modification is a change to the technical specifications of the dimensions, engines, and / or the carrying capacity of motorized vehicles.

Based on this, it is explained that every party wishing to make modifications or their motorized vehicle is required to have a license for the modification as required in Act No. 22 of 2009 concerning Road Traffic and Transportation and PP Number 55 of 2012 concerning vehicles. If the modification is carried out without having a permit and without passing the type test, then based on Act No. 22 of 2009 concerning Road Traffic and Transportation Article 277.

Anyone who brings a Motor Vehicle, trailer and attached carriage to the territory of the Republic of Indonesia, manufactures, assembles, or modifies a Motor Vehicle which causes a change in type, trailer, trailer, and special vehicle operated domestically which does not fulfill the obligation. roadworthiness type test, quality test and endurance test as referred to in Article 50 paragraph (1) shall be punished with imprisonment of a maximum of 1 (one) year or a maximum fine of IDR 24,000,000.00 (twenty four million rupiah).

Currently Bentor is indeed an alternative transportation. However, until now there has been no official regulation legalizing Bentor. The Bentor vehicle is strictly prohibited because the transportation itself is modified by the owner without any clear rules and for the place where the Bentor is made, there will be action or arrest because this action is a criminal act. There are no standards set by the government, both central and regional, that can be used as a benchmark for legalizing the presence of benthors. In addition, the use of benthors on the highway is not safe. There are no safety standards, so people are also advised not to use Bentor services ${ }^{2}$.

Bentor riders refer to Article 77 of Act No. 22 of 2009 concerning Road Traffic and Transportation, which states that drivers are required to have a driving license according to the type of vehicle being driven. This article has penalties stipulated in Article 281 which states that every person driving a motorized vehicle on the road that does not have a driving license as referred to in Article 77 paragraph (1) will be subject to a maximum imprisonment of 4 months or a maximum fine of Rp1. 000,000 (one million rupiah). But the presence of Bentor is also able to compete with public transportation cars and taxis, because of its strong design, the mileage can also be hundreds of kilometers. In fact, to go to a location and shopping center, the people of Semarang tend to use Bentor, because it is easy to enter access that is difficult to pass by public transportation cars. From the explanation on the motorized pedicab vehicles, which are still operating on public roads without proper vehicle number and letter signs, as well as the lack of security for motorized pedicabs, especially in the city of Semarang. Therefore, researchers are interested in examining from the perspective of law enforcement on the operation of motorized pedicabs in the jurisdiction of Semarang City in the perspective of Act No. 22 of 2009 concerning Road Traffic and Transportation ${ }^{3}$.

\footnotetext{
2 Ma'ruf Umar and Aga Wigana. (2020). Telaah Bukti Penyadapan Telepon Dalam Perkara Tindak Pidana Korupsi. Semarang: Badan Penerbit UNISSULA PRESS. p. 19

${ }^{3}$ Azwar, Saifudin. (2014). Metode Penelitian. Yogyakarta: Pustaka Pelajar. p. 47
} 
The law must be enforced and enforced. Everyone expects that the law can be stipulated in the event of a concrete event. How the law should apply, basically it cannot be deviated: Fiat Justicia Et Pereat Mundus (even though the world will collapse, the law must be enforced) is what legal certainty wants. Such is the case in law enforcement against Bentors in the jurisdiction of the Semarang Police.

\section{Research Methods}

The approach Method in this research is Juridical Empirical, a way to solve research problems by examining secondary data first and then continuing research on primary data in the field. Research Specifications: descriptive analysis, focusing on the problem and then processed and analyzed to draw conclusions. Data collection methods, namely dprimary data: interviews and secondary data: relevant literature studies, either in the form of theories or opinions from experts documented in the literature. Data Analysis Methods: qualitative analysis, namely by describing the data in the form of regular, logical and effective sentence ${ }^{4}$.

\section{Result and Discussion}

\subsection{The cause of the large number of pedicap being modified to become motorized pedicap in the jurisdiction of the Semarang Police}

The provisions of the technical requirements for motor vehicle modification in Act No. 22 of 2009 are contained in Article 50:

a. The type test as referred to in Article 49 paragraph (2) letter a shall be carried out for every Motor Vehicle, trailer and attached carriage imported, manufactured and / or assembled domestically, as well as modification of Motor Vehicles causing a change in type. .

b. Type test as intended in paragraph (1) consists of:

1) physical testing to fulfill the technical requirements and roadworthiness which is carried out on the foundation of Motorized Vehicles and Motor Vehicles in complete condition; and

2) research on the design and engineering of Motor Vehicles carried out on houses, troughs of cargo, trailers, attached carriages, and modified Motor Vehicles.

As for the provisions regarding Article 1 number 12 in Government Regulation Number 55 of 2012 concerning vehicles (PP No 55/2012), it explains that motor vehicle modification is a change to the technical specifications of the dimensions, engines, and / or the carrying capacity of motorized vehicles.

Based on this, it is explained that every party wishing to make modifications or their motorized vehicle is required to have a license for the modification as required in Act No. 22 of 2009 and Government Regulation Number 55 of 2012. If the modification is carried out without a license and without passing type test, then based on Act No. 22 of 2009:

\footnotetext{
4 Soekanto, Soerjono \& Sri Mamudji. (1985). Penelitian Hukum Normatif Suatu Tinjauan Singkat. Jakarta: Raja Grafindopersada. p. 66
} 
The reads of Article 277; Anyone who brings a Motor Vehicle, trailer and attached carriage to the territory of the Republic of Indonesia, manufactures, assembles, or modifies a Motor Vehicle which causes a change in type, trailer, attached carriage, and special vehicles operated domestically which do not fulfill the obligation. roadworthiness type test, quality test and endurance test as referred to in Article 50 paragraph (1) shall be punished with imprisonment of a maximum of 1 (one) year or a maximum fine of IDR 24,000,000.00 (twenty four million rupiah).

Based on the results of interviews the author conducted with Mr. Sugito, Semarang Police Investigator, the cause of the many pedicap being modified to become motorized pedicap in the jurisdiction of the Semarang Police Traffic Unit is as follows:

a. The cause of the conversion of pedicab pedicabs to motorized pedicabs is the increased income of the rickshaw owners, where motorized pedicabs move faster and use less energy so that it is faster to get passengers to get to their destination

b. The potential of Bentor as urban transportation shows an increase, this is due to the increasing need for transportation facilities and also transportation service areas that cannot be served by other means of transportation.

c. Due to the difficulty of finding work, many have chosen to become Bentor motorbikes

d. There is a lot of unemployment, so people tend to look for jobs that are easy, namely to become bent

\subsection{Law enforcement of Act No. 22 of 2009 concerning Road Traffic and Transportation against bumps in the jurisdiction of the Semarang Police}

Law enforcement against Bentor violations in the jurisdiction of the Semarang Police Unit refers to Article: 277 Act No. 22 of 2009 concerning Road Traffic and Transportation, namely the criminal act of traffic in the manufacture, assembly and modification of branded motorbikes into motorized pedicap (Bentor) by Mr. Kardono Bin (Alm) Samsuri, because the elements formulated in Article: 277 of Act No. 22 of 2009 concerning Road Traffic and Transportation, it states that every person who enters a motorized vehicle, trailer and attached carriage into the territory of the Republic of Indonesia, makes, assembles, or modifies a trailer, patch car, and special vehicles operated domestically that do not fulfill the type test obligation as referred to in Article 50 paragraph (1) shall be punished with a maximum sentence of 1 (one) year or a maximum fine of IDR 24,000,000, (twenty four million rupiah).

In law enforcement theory, where in upholding the law, there are three elements that must be considered or fulfilled by the Semarang Police Precinct, namely as follows:

a. Benefits ; The public expects benefits in implementing or enforcing the law with the existence of Act No. 22 of 2009 concerning Road Traffic and Transportation. Law enforcement or law enforcement against Bentor enforcement in the jurisdiction of the Semarang Police Resort must provide benefits and benefits to 
the community. Don't because the law is implemented or enforced, it will cause unrest in the community.

b. Justice; Act No. 22 of 2009 concerning Road Traffic and Transportation is the main legal objective in addition to legal certainty and expediency. Justice itself is closely related to the distribution of rights and obligations. Among the rights possessed by humans, there are a number of rights that are fundamental in nature as a gift from the one and only God, which are called human rights. The obligation of the community, especially in the jurisdiction of the Semarang Police, must comply with and pay attention to Act No. 22 of 2009 concerning Road Traffic and Transportation, which is an indication of driving.

c. Legal certainty; Act No. 22 of 2009 concerning Road Traffic and Transportation must be implemented and enforced in enforcing the existence of bumps in the jurisdiction of the Semarang Police Headquarters. Everyone expects that the law can be enacted in the event of a concrete event. How is Act No. 22 of 2009 concerning Traffic and Road Transportation which must apply, must not deviate and must be firm in applying it to violators of the law.

The factors that influence law enforcement will be related to the issues of Act No. 22 of 2009 concerning Road Traffic and Transportation against bumps in the Semarang Police's jurisdiction and the theory of legal effectiveness as follows:

a. Legal subtance (legal substance)

b. Legal Structure (legal structure).

c. Legal culture (legal culture) or Community and Cultural Factors

d. The factor of means that support law enforcement so that it runs smoothly.

e. Community factors, namely the environment in which the law applies.

\subsection{Barriers and solutions in overcoming the modified rickshaw law enforcement in the jurisdiction of the Semarang Police}

Based on an interview with Mr. Sugito, a Semarang Police investigator, there are several obstacles in enforcing the law against bumps in the Semarang Polrestabes jurisdiction, namely as follows:

First, the law enforcement factor. The police should firmly take action against all Bentor drivers even though they have complete documents and driver's license, because the vehicle is deemed not meeting technical and roadworthy requirements.

Another obstacle faced by the police is the facility or facility factor, namely in the case of confiscation of vehicles where the police cannot secure a large number of bumps because the facilities used to transport the bumps are insufficient in the number of Bentors in Semarang.

The last factor found by the author is the community factor where the low level of public awareness of the enactment of Act No. 22 of 2009 concerning Road Traffic and Transportation will hinder law enforcement by the Police, besides that the community also does not understand the consequences that will be received if they are still I just use Bentor and the community also feels that it benefits from the presence of Bentor so that the minimum number of people who report to the Police regarding this problem. Bentor riders, In addition, Bentor drivers think that if they 
have a complete vehicle certificate and driver's license, they can freely use the Bentor.

\subsection{Solutions in overcoming obstacles}

In the process of research activities, based on observations and interviews, there are several factors that arise in overcoming the problem, namely the coordination of the Semarang Police and the Semarang City Transportation Agency in enforcing the law on motorized pedicabs in Semarang City as follows:
a. Unity of Action
b. Communication
c. Division of work
d. Strengthening through law

\section{Conclusion}

Law enforcement refers to Article 277 of Act No. 22 of 2009 concerning Road Traffic and Transportation, namely the criminal act of traffic in the manufacture, assembly and modification of branded motorbikes into motorized pedicap (Bentor), which was carried out by Mr. Kardono Bin (Alm) Samsuri, because the elements formulated in Article: 277 of Act No. 22 of 2009 concerning Road Traffic and Transportation. The solution in overcoming obstacles is by coordinating the Semarang Police with the Semarang City Transportation Agency in enforcing the motorized pedicab law in the city of Semarang as follows: Unity of action, communication, division of labor and strengthening through law.

\section{References}

Books:

[1] Azwar, Saifudin. (2014). Metode Penelitian. Yogyakarta: Pustaka Pelajar

[2] Ma'ruf Umar and Aga Wigana. (2020). Telaah Bukti Penyadapan Telepon Dalam Perkara Tindak Pidana Korupsi. Semarang: Badan Penerbit UNISSULA PRESS

[3] Soekanto, Soerjono \& Sri Mamudji. (1985). Penelitian Hukum Normatif Suatu Tinjauan Singkat. Jakarta: Raja Grafindopersada

\section{Regulations:}

[1] Act No. 22 of 2009 concerning Road Traffic and Transportation

[2] Government Regulation Number 55 of 2012 concerning vehicles 